\title{
Pigs, pastures, pepper pickers, pitchforks: Carl Sandburg's Rootabaga Stories and the tall tale
}

\author{
Michael Heyman \\ Berklee College of Music \\ mheyman@berklee.edu
}

\begin{abstract}
Past studies of American nonsense literature have tended to lump it together with the British, for many good reasons. This article, however, distinguishes American nonsense from the British by way of its folk origins and cultural context. One of the least-recognized writers of nonsense is Carl Sandburg, who is famous for his iconic American poetry, but his Rootabaga Stories (1922-30) are some of the best and most distinctive representatives of the genre. Sandburg's nonsense short stories are lyrical and strange, but their value lies also in their distinctive American origins. They are distinguished in having particularly American themes, cultural tendencies, and geography, but also in their formal techniques, which hearken back to American folklore and the tall tale in particular, as in W. B. Laughead's Paul Bunyan (1922).
\end{abstract}

Keywords: humour, nonsense literature, America, tall tale, Paul Bunyan.

When Noel Malcolm argued, in The Origins of English Nonsense (1997), that literary nonsense texts were not derived in any significant way from the folk tradition, he bucked over a hundred years of critical opinion, including, I should note, my own. And while my first reaction was to buck right back, I grew less buckful upon considering the significance of Malcolm's subject being, specifically, nonsense from England. His argument, indeed, has validity when we consider that Lewis Carroll, for instance, may parody nursery rhymes in the Alice books, but the method by which the parody works owes much more to the subversive and madcap intellectual nonsense of the sixteenth and seventeenth centuries, spearheaded by well-known (at the time) wits such as John Hoskyns (1566-1638) and John Taylor (15781653), than to Mother Goose and "Hey Diddle Diddle" (Malcolm 1997: 4). These arguments notwithstanding, I found myself, inexplicably, still defensive-until I realized that my indignation came, in part, from my experience with nonsense literature usually undifferentiated from the English: the work of Americans such as Gelett Burgess, Dr. Seuss, and Edward Gorey. One nonsense corpus in particular, that of Carl Sandburg, seemed most saturated in the American folk tradition, and, in a way that Malcolm might agree with, most representative of an American school distinct from the British. It is this distinction that I hope to explore in this paper: the close relationship of American nonsense to folk origins, not just 
in terms of theme, but in particular, method. This investigation will lead us, by zigzag railway, to a most archetypically American landscape, with the wide prairies, stretching skyscrapers, and corn-fed hucksters of Carl Sandburg's Rootabaga Stories.

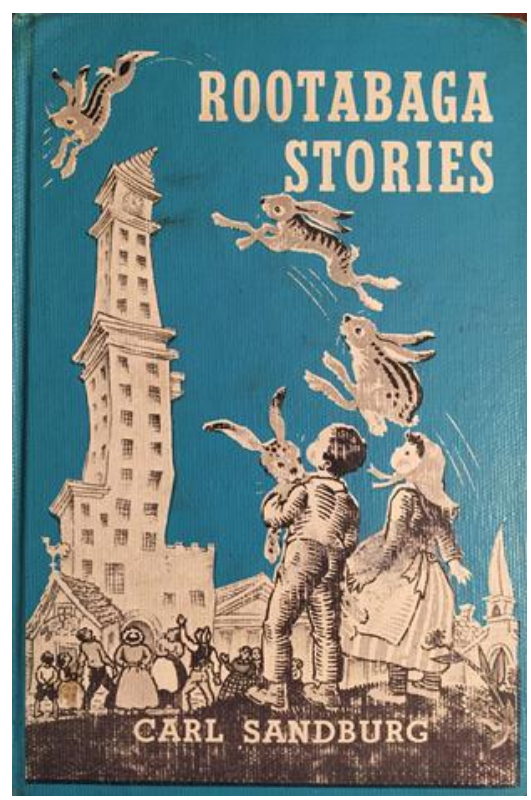

Figure 1. Cover of 1950s edition of Sandburg. (Sandburg 1951: cover image.)

Perhaps the most significant obstacle to distinguishing American nonsense from the British is that the very definition of nonsense literature is derived ostensively from the work of two Victorian Englishmen, Edward Lear and Lewis Carroll. The closer a text is to their classics, like Lear's "The Owl and the Pussy-cat" and "The Story of the Four Little Children Who Went Round the World" (1871), or Carroll's Alice's Adventures in Wonderland (1865), the more critics around the world tend to label it nonsense-and for some good reasons: the genre classification did not even exist before their work (though this style of writing itself $d i d$ in various prototypical forms).

Nonsense literature, as it was employed by these English gentlemen, is also characterized by a nexus of certain playful pranks of language and logic that function more or less the same in many cultures. Logical reversals and inversions, arbitrariness, faulty cause and effect, neologism, and misappropriation are only a few of the shared tools available to sense tinkers and ticklers. These methods contribute to what Wim Tigges calls the necessary unresolved tension in relating "a multiplicity of meaning with a simultaneous absence of meaning" (Tigges 1988: 47). The end result, importantly, is not gibberish; as T.S. Eliot said in a lecture on poetry, Lear's nonsense "is not vacuity of sense: it is a parody of sense, and that is the sense of it" (Eliot 1953 [1942]: 56). Meaning arises in unexpected ways-ways that go beyond, one might say, our traditional strategies of sense-making. One of the first serious critics of nonsense, Edward Strachey, got the point all the way back in 1888: "Nonsense has proved not to be an equally prosaic and commonplace negative of Sense, [...] but the bringing out a new and deeper harmony of life in and through its contradictions" (Strachey 1888: 335).

The type of parody mentioned by Eliot, a parody existing beneath the level of genre, is also what helps to distinguish nonsense, wherever it may be found, from related genres such as fantasy. Indeed, nonsense is often found within a fantasy world, but the preponderance of nonsense devices, parasitic in nature, transports us beyond whichever genre may be playing host. Along these lines, Jean-Jacques Lecercle suggests that Lewis Carroll's nonsense parodies in the Alice books, like "I'll tell thee everything I can" (otherwise known as "A- 
Sitting on a Gate," "Haddock's Eyes," etc.), are a kind of imitative "refraction," using Bakhtin's term, of any given source text (in Carroll's case, a "refraction" of Wordsworth's "Resolution and Independence"). Parodic nonsense "refraction," he explains, "is not merely distortion, but also inscription. A nonsense text literally inscribes other texts through ironic quotation-this is the distance of parody" (Lecercle 1994: 169-70). Nonsense thus chisels itself, graffiti-like, over its source, be it a poem or a genre, but this is no defacement; rather, it is a rich new work that rests, however uneasily, over the old. ${ }^{1}$

These more universal formalistic and generic elements of literary nonsense were not invented by Edward Lear and Lewis Carroll, but it was their nonsense, employing these characteristics, that spread alongside the British Empire. And because the theoretical definitions of nonsense (and "sense," as must follow) get mighty heady, definition by example (as in, relating to Carroll and Lear in particular) is the method most commonly employed, even though it carries considerable cultural imperialism. And thus we are brought back to the difficulty in trying to move beyond the British model.

Another aspect of the problem of distinguishing American nonsense from the British is that it comes, in part, from us, who were they, or, contrariwise, they who were we. Some of the very best "American" nonsense (though not for children) came, for instance, from the Tuesday Club, established by the transplanted Scotsman Dr. Alexander Hamilton (17121756), in colonial Maryland. Such clubs should be, claimed Hamilton, "free, frolicksome, gay, and Gamesome" (Hamilton 1995: 22), though his own rough-hewn illustration (Fig. 2), with its fits and fights, shows the contradictory chaos and aggression behind such sportiveness.

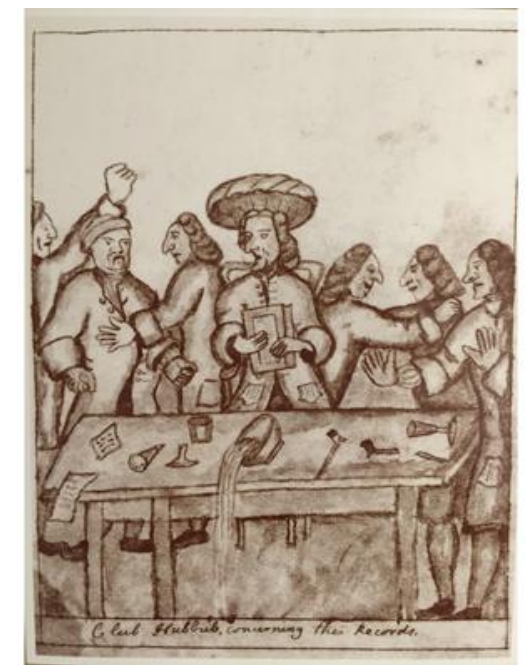

Figure 2. Dr. Alexander Hamilton's rendition of The Tuesday Club, or "Club Hubbub," here. (Hamilton 1995: cover image.)

The Club's members should be "merry, droll, facetious, Jocose, good humored, risible companions, punsters, comical Story tellers, and Conundrumifiers," and by no means should they admit

Your Insipid, havy dull drivelling moralizers, Criticisers and Censors of the times [...] who will draw a moral Conclusion, out of a decayed turnip, or rotten Cheese, and gravely infer from thence, that all flesh is grass...

(Hamilton 1995: 22)

Such clear enemies of nonsense and jollity, Hamilton advises, should be shut up in caves with ascetics and hermits, and forgotten. But the puns and logical leaps in The Club's impressive 
and impressively silly "history" are hard to distinguish from contemporary British intellectual lunacy.

Fast-forward to the present and our British gene still seems dominant. The work of one of the greatest American nonsense writers, Edward Gorey (1925-2000), looks so Victoriancum-Edwardian English that many folk believed him to be English — and dead long before his actual demise. To know we are in some British Twilight Zone, we need only look to The Doubtful Guest (1957) to see the stiff tweeds, the pocket watch, and a tureen (a word many would probably recognize from the Mock Turtle's song in Alice's Adventures in Wonderland). Another corker is The Hapless Child, where the father, "a colonel in the army, was ordered to Africa" (Gorey 1972 [1961]: n.p.), armored in his pith helmet and mustachios. Indeed, while some English nonsense artists like Mervyn Peake may not have thrived in America, the popularity of others like the comedy troupe Monty Python has surely made up for it, colouring American nonsense always with shades of British racing green.

One last obstacle in splitting the Anglo- and the American is a technical one: the differentiation between thematic content and formalistic technique. Those who get so far as to consider American nonsense as something worth separate study probably think, at first, of Dr. Seuss, by far the best-selling American nonsense writer. Philip Nel argues that Dr. Seuss is the "unacknowledged U.S. laureate of nonsense poetry" (Nel 2004: 16), and while that is certainly debatable (what of Gorey?), the American-ness of his work is less so, with bold anarchical individuals like the Cat in the Hat (1957), fantastic technological contraptions like McBean's Star-Making Machine from The Sneetches (1961), and the "biggering" expansion of business in The Lorax (1971):

I biggered my factory. I biggered my roads.

I biggered my wagons. I biggered the loads

of the Thneeds I shipped out. I was shipping them forth

to the South! To the East! To the West! To the North!

(Seuss 1971: n.p.)

Beyond these overtly "American" themes, the "messages," in most of his books, far from being nonsensical or containing a balanced tension between meaning and non-meaning (as Tigges requires), are mostly pellucid (Don't cut down trees for garsh sakes! Mind the environment! War is stupid!). We might even see Seuss's moral-slinging as following in the nineteenth-century American tradition of Peter Parley, that most practical-minded child friend, who thought that books for children were valuable insomuch as they unambiguously served the goal of utility. However, when it comes to the way that he creates the actual nonsense - his linguistic and logical formal techniques - it is hard to see how his work is so culturally distinguished. In The Lorax, above, he uses a neologism, "Thneeds," for instance, but there is nothing in this technique to distinguish it from the English tradition (think "Jabberwocky") - let alone most every other nonsense tradition in the world. One could argue, as Nel does, that Seuss is the best writer of nonsense who is American-but that may be quite different from the best writer of American nonsense. ${ }^{2}$

While Seuss is certainly worthy of study as an American writing nonsense (and Nel's $D r$. Seuss: American Icon [2004] and his The Annotated Cat: Under the Hats of Seuss and His Cats [2007] are great resources), I would like to present a rather obscure alternative that I hope represents even better the functioning of both sides, thematic and formalistic, of American nonsense: Carl Sandburg's great and greatly unrecognized masterworks of American nonsense, Rootabaga Stories (1922), Rootabaga Pigeons (1923), and Potato Face (1930). Carl Sandburg's poetry, of course, is widely known as the broad-shouldered progeny of America's heartland, but it is shocking how little attention has been given to his considerable output for children and especially his deep dive into nonsense literature. 
The Rootabaga series of loosely connected short stories is set not in a European "king's castle behind a moat menaced by wicked enchanters or witches" (Hoffman 1979: n.p.), but in the "native soil" (Hoffman 1979: n.p.) of a fantastical American Midwest called the Rootabaga Country. Amidst the wide-open prairies and cornfields sit the Village of Liverand-Onions and the smaller Village of Cream Puffs, which has to be tethered down with rope so that when it blows away in the winds (cue Dorothy and Toto), it can be reeled back in. Rootabaga Country is populated not by cardboard princesses and princes, but rather by humble country folk: farmers, laborers, policemen, thieves, and street corner philosophers, in addition to rusty rats, spider jackrabbits, Potato Bug Pigs, and even talking rag dolls, broom handles, and skyscrapers. To get there, we first follow Gimme the Ax and his mysteriouslyacquired family in "How They Broke Away to Go To the Rootabaga Country," the first in Rootabaga Stories:

Gimme the Ax lived in a house where everything is the same as it always was.

"The chimney sits on top of the house and lets the smoke out," said Gimme the Ax. "The doorknobs open the doors. The windows are always either open or shut. [...] Everything is the same as it always was."

So he decided to let his children name themselves.

"The first words they speak as soon as they learn to make words shall be their names," he said. "They shall name themselves."

When the first boy came to the house of Gimme the Ax, he was named Please Gimme. When the first girl came she was named Ax Me No Questions.

And both of the children had the shadows of valleys by night in their eyes and the lights of early morning, when the sun is coming up, on their foreheads.

And the hair on top of their heads was a dark wild grass. And they loved to turn the doorknobs, open the doors, and run out to have the wind comb their hair and touch their eyes and put its six soft fingers on their foreheads.

$[\ldots]$

After a while they began asking each other in the cool of the evening after they had eggs for breakfast in the morning, "Who's who? How much? And what's the answer?"

(Sandburg 1951 [1922]: 3-5)

In this passage there is a strangeness, a wide-openness, a wind-swept mythic resonance, with echoes of Gertrude Stein's echoes and the wistful lyricism of Edward Lear, too. We have the American themes of wide-open spaces, of self-determination, even selfishness. The children, despite being self-named, are hardly individuated from the wild landscape. These are all markers of the text being distinctly American, but not necessarily American nonsense.

Nonsense there is, though, beginning with the inexplicable stating of the obvious, as with the function of the chimneys and doorknobs. The topsy-turviness of the evening coming immediately after morning breakfast also hearkens back to medieval impossibilia, part of the collective roots of nonsense literature. The final open-ended (and unanswered) questions, "Who's who? How much? And what's the answer?" may connect, in loose ways, to the children's naming or Gimme the Ax's existential dilemmas, but the questions' repetitiveness, their lack of direct reference, and their open-endedness create the requisite nonsensical tension between much and nothing, ultimately leaving us with a deficiency of signification, one of Tigges' hallmarks of nonsense.

More subtle, and because of this, perhaps even more effective, as least according to Stephen Booth's definition of nonsense as functioning, in part, because "ideationally insignificant coherence often takes the place of, does the job of, the ordinary, substantive, syntax-borne coherence that we expect, demand, and do not notice is absent" (Booth 1998: 8), are the instances of nonsense that tend to slip by us as we assume them to make sense. This occurs, perhaps, with the temporal incongruity, or impossible simultaneity, of the children, 
seemingly newly arrived to the world, being able to name themselves, after our just having learned that they must first go through the process of learning how to make words. And then there are the names themselves, creating a logical tension in causality. That is, the words "Gimme" in "Please Gimme" and "Ax" in "Ax Me No Questions" imply a patronymic origin (one word each from "Gimme the Ax"), and yet the words co-exist in the context of the "first words they speak." That their father's name figures in their first words implies a strange causal relation between linguistic contexts, the semiotic versus the literal (with the additional complication of "ax" being substituted for "ask"). Adding to the ambiguity of these words in the children's names is the factor, discussed below, of their possibly having a connection to some American Indian methods of naming with a narrative origin.

The nonsense continues as Gimme the Ax's growing family determines that "it is too much to be too long anywhere," and so after selling all their "pigs, pastures, pepper pickers, pitchforks, everything they had except their ragbags and a few extras" (Sandburg 1951 [1922]: 5-6), they head to the train station, where the ticket agent asks,

"Do you wish a ticket to go away and come back or do you wish a ticket to go away and never come back?" [...]

"We wish a ticket to ride where the railroad tracks run off into the sky and never come back-send us far as the railroad rails go and then forty ways farther yet," was the reply of Gimme the Ax.

"So far? So early? So soon?" asked the ticket agent....

(Sandburg 1951 [1922]: 9)

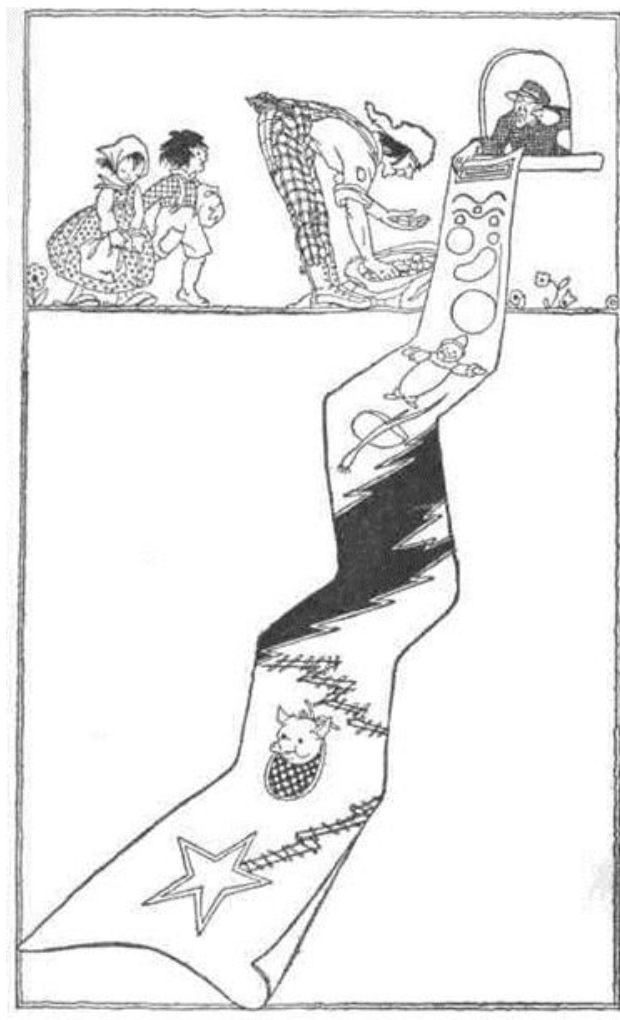

Figure 3. From Rootabaga Stories, illustrations by Maud and Miska Petersham (Sandburg 1951 [1922]: 7).

Just as the exaggerated physical ticket with the nonsensical blue "spanch" across it begins to cross the illustration's frame, so the family moves beyond that which is known: beyond the rail frontier, beyond gravity, and beyond reason (for what does "forty ways farther yet" mean, 
exactly?). The ticket, the family, the story, and the nonsense mechanisms have moved into the mythic territory of tall tales - a distinct feature and function of American nonsense literature.

To understand this kind of journey, we would do well to look at its origin, to a great extent, in American folklore. This element is stronger in much American nonsense, as opposed to the British, as a result of its being a more dominant part of the overall culture. In other words, classic American nonsense, like the American "classical" music of jazz, tends to owe more to the folk than the elite. This is not to say that the English tradition has no tall tales, or that its nonsense is uninfluenced by this folk tradition-it has, and it is not-only that Sandburg's American nonsense incorporates and develops these more than the English. Sandburg, it should be noted, was also a renowned folklorist, and his annotated music compilation, The American Songbag (1927) remains a classic resource for folk music. It contains a wealth of nonsense songs (see "The Horse Named Bill" or "Good-By Liza Jane" for instance), and also stands as a catalogue of sorts for American folklore, including heroes such as Casey Jones, John Henry, Jesse James, and Railroad Bill. As Sandburg himself notes, though, one odd absence in these songs is Paul Bunyan, perhaps the biggest American folk hero (Sandburg 1990 [1927]: 400).

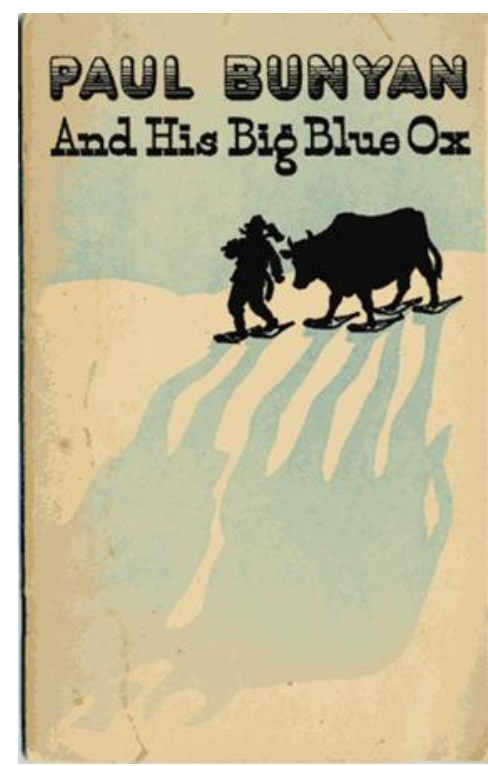

Figure 4. Cover of 1922 Paul Bunyan (Laughead 1922: cover image).

W.B. Laughead's 1922 version of Paul Bunyan, with the bluster and boom of tall tales, turns out to be an American nonsense prototype. Below, we see a description of Paul's famous companion, Babe the Blue Ox:

Once in a while Babe would run away and be gone all day roaming all over the Northwestern country. His tracks were so far apart that it was impossible to follow him and so deep that a man falling into one could only be hauled out with difficulty and a long rope. Once a settler and his wife and baby fell into one of these tracks and the son got out when he was fifty-seven years old and reported the accident. These tracks, today form the thousands of lakes in the "Land of the Sky-Blue Water."

(Laughead 1922: n.p.)

Of course, we can point out the thematic American material here, much of it similar to the Rootabaga Stories: the Western expansion of settlers in the "Northwestern country," the open spaces, and also the modern origin story of the "Land of the Sky-Blue Water," considering 
that America was a fairly new country, lacking ancient lore (though this seems also to borrow from the origin stories of the American Indians). Sandburg, we should note, also contributes a fair number of origin stories, such as "How Gimme the Ax Found Out About the Zigzag Railroad and Who Made It Zigzag."3

Also connecting Laughead's versions of the folklore and Sandburg to American Indian tradition is the employment of literal, even narrative nomenclature. American Indian names, depending on region and tribe, often come from literal meanings and sometimes events or actions, giving them additional weight in terms of their mythic and/or cultural resonance. Even though such names do not necessarily do this, the common perception of them, outside of native communities, is that they do - and thus the use of these techniques, accurate or not, can signal "American Indian" to some non-Indian Americans. Even Sandburg and Laughead, though professional folklorists of their day, were still probably prone to misinformation and negative and inaccurate stereotypes of American Indians. Sandburg's "Gimme the Ax," for instance, may indeed have resonated with the contemporary audience as vaguely (and menacingly) "Indian."

The names that pop up in Laughead reflect this native Indian heritage (or the white conception of it) while adding a little practical and blunt American grit. The names betray size, power, and perhaps most importantly, utility. Idle hands would never be found on Brimstone Bill, for instance. Big Old, Sourdough Sam, Chris Crosshaul, and Johnny Inkslinger are all hard-working men, working Americans whose utility is so intrinsic it inhabits their names. Indeed, some of Sandburg's odd character names follow Laughead's experience-based nomenclature. In "How Bozo the Button Buster Busted All His Buttons When a Mouse Came," for instance, Hatrack the Horse tells Deep Red Roses, The Beans Are Burning, and Sweeter Than the Bees Humming, the story of Bozo the Button Buster. He begins with the name's origin: "Bozo had buttons all over him [...] the buttons on Bozo fitted so tight, and there were so many buttons, that sometimes when he took his lungs full of new wind to go on talking a button would bust loose and fly into the face of whoever he was speaking to" (Sandburg 1951 [1923]: 64-65). While not all of the names are addressed, in terms of origins, the name of the story's protagonist gets a full, clear explanation. This pattern of name-origin recognition occurs enough that we might expect it with most of the unusual names in the stories; however, our expectations are often dashed-in nonsensical ways.

Sandburg takes the blunt and beefy American names further towards nonsense in a mixture of wild exaggeration, pseudo-American Indian image-names, mystery, utility, and slapstick. We have already met Gimme the Ax, Please Gimme, and Ax Me No Questions, but almost every story seems to introduce new and stranger folk, like Potato Face Blind Man (perhaps the most recurring character), Slipfoot, Any Ice Today, the Shaghorn Buffalo, Bimbo the Snip, Snoo Foo, and Hot Balloons, to name only a few. These names beg many questions, partly because of their sheer absurdity and mystery, and partly because of the pattern of carefully explained origins, as we have seen with Bozo the Button Buster.

Defying the pattern are characters like Dippy the Wisp and Slip Me Liz. When these sisters first meet Potato Face Blind Man, we only find out that they "came, two tough pony girls, two limber prairie girls, in the moonshine humming little humpty dumpty songs" (Sandburg 1951 [1923]: 116). A later story in this volume, "Hot Balloons and His Pigeon Daughters Crossed into the Rootabaga Country" gives further physical description of them: "looking fresh and free as two fresh fish in a free river, fresh and free as two fresh bimbos in a bamboo tree" (Sandburg 1951 [1923]: 136). Needless to say, these descriptions (especially the latter) further the nonsensical tension rather than answering any questions about their names' provenance. Some sense implication occurs in the word "Dippy," as the story "How Two Sweetheart Dippies Sat in the Moonlight on a Lumber Yard Fence and Heard About the Sooners and the Boomers" includes a nonsensical origin story for the "dippies"-however 
Dippy the Wisp is never directly associated with these other "dippies," and so their connection remains unknown. Of course, "Wisp" might imply simply a physical attribute of slimness, associated, perhaps with a "dippy" - making this name slightly more explainable. The name Slip Me Liz, however, has a more murky derivation. Does it imply a narrative or a command? Does it have any relationship with ponies or the prairie or their singing of folk rhymes or fresh fish or free rivers? Is there some other character named Elizabeth (or "Liz") to whom this refers? If these two girls are sisters, why is only one possibly named for what she is, if indeed, she is a "dippy" at all? Answers, there are none.

To compound the naming mystery, these sisters introduce their pet bees, with names even more explicitly nonsensical in terms of their implied origins. In particular, the names' concreteness and referential specificity belie the lack of connection to the bees' one noted feature: "This is Egypt — she has inkwells in her ears. This is Jesse James - he puts postage stamps on his nose. This is Spanish Onions - she likes pearl-color handkerchiefs around her yellow neck" (Sandburg 1951 [1923]: 117). Of course, Western names, generally speaking, need have no meaning, narrative or otherwise; but these names, in such close proximity to unrelated (and nonsensical) qualities, and in the context of origin stories and, indeed, an established partial-pattern of name explanation, retain the nonsense tension in the logic of naming.

Name-creation is one of the ways where we can see a progression from Laughead to Sandburg which merges traditional American culture and technical linguistic construction. Another way, and even more significant to the "American-ness," is the method by which Laughead arrives at something like proto-nonsense. To return to the story of Babe the Blue Ox and the settler's family, it, like the very best and extreme tall tales, borders on the nonsensical. The son popping out of the hole fifty-seven years later not only exaggerates the exaggeration, but it begs many how and why questions unrelated to the depth of the hole or Babe's size. As we saw earlier with Carroll's "I'll tell thee everything I can," nonsense tends to shine, as here with Babe, when it overshadows genre (in this case tall tale), becoming something entirely stranger. When Babe is introduced a little earlier, we learn that

Babe, the big blue ox constituted Paul Bunyan's assets and liabilities. History disagrees as to when, where and how Paul first acquired this bovine locomotive but his subsequent record is reliably established. Babe could pull anything that had two ends to it.

(Laughead 1922: n.p.)

The last line here is simple - but simple like a koan. It takes on nonsensical proportions when we consider its implications in theoretical physics. Babe's comparison to a locomotive brings to mind lines of rail cars stacked with cords of wood. Yet, doesn't everything, or, at least all things beyond the first dimension, have at least "two ends"? What about Paul Bunyan's enormous round pancakes? What about Sandburg's "hot hankypank cakes"?

Such quasi-mystical conundrums bring us back to the departure of Gimme the Ax and family from Rootabaga country, when they are asked if they "wish a ticket to go away and come back or [...] a ticket to go away and never come back?" In this scene, we see a gathering of the American nonsensical elements rooted in Laughead's whoppers. The nonsense begins functioning here a little like the Dormouse's "correction" to Alice's assertion that saying "what she means" is the same as her meaning "what she says." $\mathrm{He}$ points out her error, likening it to the foolishness of thinking that "I I breathe when I sleep' is the same thing as 'I sleep when I breathe"” (Carroll 2013 [1865]: 53). The ticket seller's statement, however, adds on to this simple Carrollean device.

There is a kind of simple logic, of course, in such reversals: just as a syntactical reversal might indeed lead to similar meaning (to alter slightly Alice's statement: "I breathe as I sleep" being roughly equal to "I sleep as I breathe," for instance), it might follow that if one 
can buy a ticket to go away and come back (a return, or round-trip), it seems that we should also be able to have the other normal option, a single or a one-way, an element implied not only by the practical situation but also by the parallel syntactic pattern, with only the word "never" there to indicate difference. Further, "To go away and never come back" is a partial, and, indeed, partially accurate, way of describing an onward journey. The additional "never" seems merely a feature of "coming back," the overall question's format still implying that there are simply two buying options, as usual. The requisite nonsense tension, of course, comes in realizing that a ticket cannot be bought for the part of a journey that is avoided, let alone the negation of a specific journey. But this is not only the impossible negation of one journey, the one Gimme the Ax is buying a ticket for (which might have been expressed as, "to go away and not come back"), it is the negation of all return journeys of the entire future of the family, an absurd stretch of the imagination. Just as with the Dormouse, exploiting syntactical implications (let alone practical ones) creates a logical slight of hand, but the effect here is multiplied by the exaggeration of an impossibility, a kind of exponential multiplication of zero. In other words, by using a reductio ad absurdum of an incongruous logical reversal, Sandburg double-dips his nonsense to create a kind of nonsense-whopper, a technique we might label as particularly American.

The logical stretches and manipulations we find in Sandburg, from purchasing a ticket for never coming back, to the impossibly stretched metaphor of going "forty ways farther yet" from the end of the rail line, point us back to the folk tradition, to the Paul Bunyan stories, full of distinctly American moxie and outrageous exaggeration, not only through the thematic material but also in the way they are constructed, their method-which is the lifeblood of literary nonsense. ${ }^{4}$ Laughead's hotchpotch of stories does not rise to the level of generic literary nonsense, but the genetics, the genretics, are clear. It is no coincidence that the Rootabaga Stories came out the same year as Laughead's volume. There may not necessarily be direct references, but the Paul Bunyan tales had been very much in the air, as they sold, indeed, like hot hankypank cakes. And while American nonsense will always betray its heritage in Britain (as does nonsense wherever the empire stretched), it strikes out on its own, down the zigzag railway, through the corn fields, and forty ways farther yet.

\section{Notes}

1 A further indicator that this is a nonsense world rather than a fantasy world is its strange relationship to magic. Most critics agree that magic has no place in a nonsense world, that it explains away the nonsense. However, as Kevin Shortsleeve argues, magic often does lurk beneath nonsense, but it usually functions to discredit the supernatural (Shortsleeve 2015: 28). At the very least, rather than making sense of the oddities of a fantasy world, "nonsense magic" only continues the tension between meaning and non-meaning. In Sandburg's "The Story of Jason Squiff and Why He Had a Popcorn Hat, Popcorn Mittens, and Popcorn Shoes," for instance, we learn of the power of the "gold buckskin whincher" (a nonsense item in itself): it says to Jason Squiff, "You have a letter Q in your name and because you have the pleasure and happiness of having a $\mathrm{Q}$ in your name you must have a popcorn hat, popcorn mittens and popcorn shoes" (Sandburg 1951 [1922]: 82). Faulty cause and effect aside, no further explanation is given of this "magic." For more on nonsense's distinction from fantasy, surrealism, Dada, Absurdism, and other related genres, see the entire chapter Wim Tigges devotes to it in his An Anatomy of Literary Nonsense (1988). 
${ }^{2}$ Hamilton, Peake, and Monty Python, matching up toe-to-toe with Seuss, Sandburg, and Gorey, would reveal much about American and British humor, but that bout will have to proceed beyond the ropes of this short paper.

${ }^{3}$ The very form of most of the titles implies origin stories, as they tend to begin with variations of "How $X$ Did $Y$ ".

${ }^{4}$ Another interesting precursor here is Gelett Burgess, whose The Burgess Nonsense Book (1901) also stands as a unique kind of American nonsense. In the piece, "On CITY FLORA," for instance, we see a confluence of tall tale, origin stories, gritty language, and even a hint of a mysterious source: "On CITY FLORA: -Semi-Culled By One whose Fame is Somewhat Dulled. // There is a Theory Some Deny / That Lamp Posts once were Three Foot High; / And a Little Boy was Terrible Strong, / And he Stretched 'em out to 'Leven Foot Long!" (1901: 20-21).

\section{References}

Booth, S. (1998). Precious Nonsense: The Gettysburg Address, Ben Jonson's Epitaphs on His Children, and Twelfth Night. Berkeley: University of California Press.

Burgess, G. (1901). The Burgess Nonsense Book. New York: Frederick A. Stokes Co.

Carroll, L. (2013 [1865]). Alice's Adventures in Wonderland, in Gray, D. J. (ed.), Alice in Wonderland. Third Edition, New York: W. W. Norton, pp. 1-97.

Eliot, T.S. (1953 [1942]). 'The music of poetry', in T.S. Eliot: Selected Prose, London: Penguin, pp. 56-67.

Gorey, E. (1972 [1961]). The Hapless Child, in Amphigorey, New York: Perigee.

Hamilton, Dr. A. (1995). The Tuesday Club, ed. R. Micklus. Baltimore: The Johns Hopkins University Press.

Hoffman, D. (1979). "Moonlight dries no mittens": Carl Sandburg Reconsidered. Washington, D.C.: Library of Congress.

Laughead, W.B. (1922). The Marvelous Exploits of Paul Bunyan. Minneapolis: The Red River Lumber Company. Retrieved September 11, 2016 from http://www.gutenberg.org/files/32994/32994-h/32994-h.htm.

Lecercle, J.-J. (1994). Philosophy of Nonsense: The Intuitions of Victorian Nonsense Literature. London \& New York: Routledge.

Malcolm, N. (1997). The Origins of English Nonsense. London: Fontana Press.

Nel, P. (2004). Dr. Seuss: American Icon. New York: Continuum.

Nel, P. and Seuss. (2007) The Annotated Cat: Under the Hats of Seuss and His Cats. New York: Random House.

Sandburg, C. (1990 [1927]). The American Songbag. San Diego: Harcourt Brace \& Company. Sandburg, C. (1951 [1922, 1923]). Rootabaga Stories. Illus. Maud and Miska Petersham. New York: Harcourt, Brace \& World, Inc.

Seuss, Dr. (1971). The Lorax. New York: Random House.

Shortsleeve, K. (2015). 'Nonsense, magic, religion and superstition'. Bookbird: A Journal of International Children's Literature. 53 (3), pp. 28-35.

Strachey, E. (1888). 'Nonsense as a fine art'. The Quarterly Review 167, pp. 335-365.

Tigges, W. (1988). An Anatomy of Literary Nonsense. Amsterdam: Rodopi. 